Article

\title{
Regulatory Compliance and Environmental Benefit Analysis of Combined Heat and Power (CHP) Systems in Taiwan
}

\author{
Wen-Tien Tsai \\ Graduate Institute of Bioresources, National Pingtung University of Science and Technology, Pingtung \\ 912, Taiwan; E-Mail: wttsai@mail.npust.edu.tw; Tel.: +886-8-770-3202; Fax: +886-8-774-0134
}

Received: 2 October 2012; in revised form: 8 January 2013 / Accepted: 10 January 2013 /

Published: 22 January 2013

\begin{abstract}
The energy conservation achieved by utilizing waste heat in the energy and industrial sectors has became more and more important after the energy crisis in the 1970s because it plays a vital role in the potential energy-efficiency improvement. In this regard, cogeneration (combined heat and power, CHP) systems are thus becoming attractive due to the energy, economic, and environmental policies for pursuing stable electricity supply, sustainable development and environmental pollution mitigation in Taiwan. The objective of this paper is to present an updated analysis of CHP systems in Taiwan during the period from 1990 to 2010. The description in the paper is thus based on an analysis of electricity supply/consumption and its sources from CHP systems during the past two decades, and centered on two important regulations in compliance with CHP systems (i.e., Energy Management Law and Environmental Impact Assessment Act). Based on the total net power generation from CHP systems (i.e., 35,626 GWh) in 2011, it was found that the carbon dioxide reduction benefits were estimated to be around $20,000 \mathrm{Gg}$.
\end{abstract}

Keywords: combined heat and power; electric power; compliance regulation; environmental benefit

\section{Introduction}

Taiwan is a small and densely populated island country (land area: $36,000 \mathrm{~km}^{2}$; population: 23 million) in the Far East (Asia) with limited natural resources. In the past two decades, the rapid industrialization and economic development have caused a high dependence on imported energy, which increased from $95.84 \%$ in 1990 to $99.39 \%$ in 2010 [1]. Meanwhile, an increase in the total carbon dioxide $\left(\mathrm{CO}_{2}\right)$ emissions from $1.11 \times 10^{8}$ tons in 1990 to $2.54 \times 10^{8}$ tons in 2010 proportionally 
occurred in parallel with the energy supply [2], 145.6 million kiloliters of oil equivalent (KLOE; $1 \mathrm{KLOE}=3.77 \times 10^{10} \mathrm{~J}$ ) in 2010 in contrast to 58.7 million KLOE in 1990 . As a result, the Executive Yuan of Taiwan adopted several regulatory and financial measures in the past two decades to encourage energy saving and renewable energy development. In this regard, the Taiwan government approved "Framework of Taiwan's Sustainable Energy Policy" in 2008 to pursue the following targets [3]:

- Improving energy efficiency by more than $2 \%$ per annum, so that energy intensity will decrease $20 \%$ by 2015 when compared with the level in 2005 ;

- Reducing nationwide $\mathrm{CO}_{2}$ emissions by developing clean energy, so that total emissions could return to its 2008 level between 2016 and 2020, and further reduced to the 2000 level in 2025 .

The energy utilization of waste heat from energy-intensive process industries (such as steel, paper, chemicals, petroleum, glass, and cement) and publicly-serviced utilities (especially in municipal solid waste incineration plants) has received much attention after the energy crisis in the 1970s because it plays a vital role in the energy-efficiency improvement potential. Combined heat and power (CHP), also known as cogeneration, is the simultaneous production of electricity and heat in one single process for dual output streams so as to greatly increase the process efficiency and decrease energy costs [4]. Also, CHP systems can avoid transmission losses in the delivery of electricity (power grid) from the central station power plant, thus decreasing the impact of outages and improving power quality for sensitive equipment. In addition to the energy saving and cost saving, the benefits of CHP system are mainly from lower air pollutants emissions to the atmospheric environment, thus reducing the greenhouse gases (i.e., $\mathrm{CO}_{2}, \mathrm{CH}_{4}$ and $\mathrm{N}_{2} \mathrm{O}$ ) and air toxics (i.e., $\mathrm{SO}_{x}, \mathrm{NO}_{x}$ and $\mathrm{Hg}$ ) emissions, which contribute to global warming and air quality, respectively.

A previous paper [5], only focused on comprehensive descriptions of the electricity supply and consumption during the period of 1984-2004 and governmental regulations for promoting industrial waste (i.e., pulp sludge, scrap wood, sugarcane bagasse, textile sludge, and scrap plastics) as energy sources, and centered on preliminary benefit analysis in the greenhouse gases reduction as a result of CHP system. In this study, the open-access documents officially published by the Taiwan central government were used to provide the updated and analytical information about the energy utilization of using CHP system in the past two decades (1990-2010). The main subjects of this paper covered the following key elements:

- Current status of electricity supply and consumption;

- Current status of electricity from CHP system;

- Regulatory compliance with CHP system;

- Preliminary benefit analysis from CHP system.

\section{Current Status of Electricity Supply and Consumption}

It is well known that a stable electricity supply plays a core role in the economic development and level of living. Prior to the mid-1990s, the Taiwan Power Company (Taipower, abbreviated to TPC), which is one of the government-owned enterprises, was entrusted with development, generation, supply, transmission/distribution, and marketing of electric power in the Taiwan area. Under the government policy on deregulation of the electric power sector and the energy saving in consideration 
of economic and environmental benefits, privately industrial plants from the energy-intensive industries (e.g., steel, paper and pulp, petrochemical and cement manufacturing) and public service utilities (e.g., municipal solid waste incineration plants) have been encouraged to install CHP systems and to sell their surplus electricity to Taipower for its own distribution. In order to maintain a stable electricity supply, the central competent authority (i.e., Ministry of Economic Affairs, MOEA) has further promoted the opening of the electric power market to Independent Power plants (IPP) in four stages during the years of 1995-2006.

As seen in Figure 1 [1], reliance on Taipower's electricity supply based on installed capacity was on the decreasing trend due to the nation's energy policy on efforts to diversify electric power sources. On the other hand, however, the reliances on IPP and CHP systems were on the increasing trend. With respect to the electricity supply (production) and consumption in the past two decades (1990-2010), some notable points were further addressed as follows [1]:

- Electricity production (power generation) grew from 90.20 Terawatt-hour (TWh) 1990, to 184.86 TWh in 2000 and 247.05 TWh in 2010. On average, an annual increase was about $5.17 \%$ in the two past decades. Of the total electricity production in 2010 , Taipower's hydro power comprised $7.13 \mathrm{TWh}(2.89 \%)$, thermal power $115.73 \mathrm{TWh}$ (46.84\%; including coal shared $26.27 \%$, oil 3.34\%, and LNG $17.23 \%$ ), nuclear power $41.63 \mathrm{TWh}(16.85 \%)$, wind power 0.52 TWh (0.21\%), CHP 40.60 TWh (16.43\%), and IPP 41.44 TWh (16.77\%);

- Electricity consumption went from 84.85 TWh in 1990 to 176.52 TWh in 2000 and 237.56 TWh in 2010, an average annual increase of $5.28 \%$. Classified by sector, energy sector (own use) used 19.22 TWh (8.09\%) of electricity in 2010, industrial sector consumed 124.15 TWh (52.26\%), transportation sector occupied $1.16 \mathrm{TWh}(0.49 \%)$, agricultural sector amounted to $2.62 \mathrm{TWh}$ $(1.10 \%)$, services sector accounted for $46.98 \mathrm{TWh}(19.78 \%)$, and residential sector took 43.43 TWh (18.28\%);

- The percent reserve margin also saw an increasing trend from $7.40 \%$ in 1990 to $12.60 \%$ and $23.40 \%$ in 2000 and 2010, respectively. It should be noted that the peak load in 2010 reached a record 33,023 MW (Megawatt).

Figure 1. Installed capacity of power generation in the past two decades (1990-2010) in Taiwan.

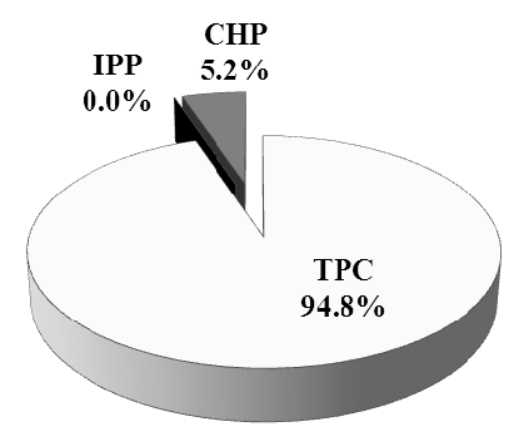

(a) 1990

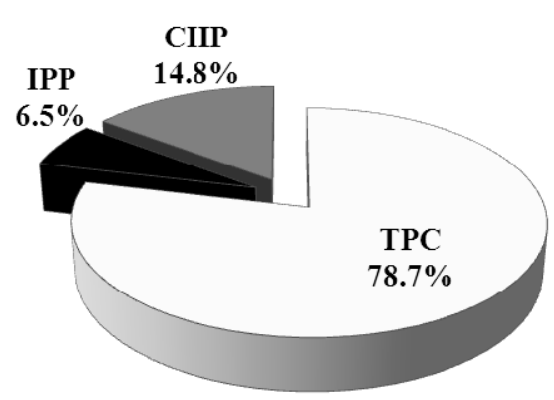

(b) 2000

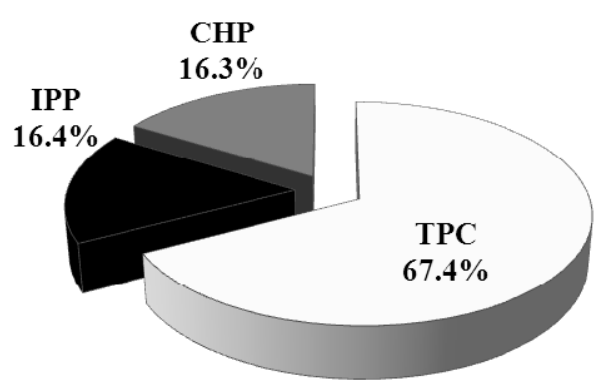

(c) 2010

\section{Current Status of Electricity Production in CHP Systems}

The energy intensity or energy use intensity is usually defined as a measurement of the energy efficiency in producing a given level of output or activity. In this regard, CHP systems are thus 
becoming attractive in the energy and industrial sectors of Taiwan. As shown in Figure 2, there has been a distinct improvement in energy intensity since 2001, from 10.13 LOE per thousand NT dollars (based on 2006 constant prices) in 2001, and then reducing to 8.22 LOE per thousand NT dollars in 2011 [1]. The percentage of the average improvement is about 3.0\%. Under the authorization of the Energy Management Law, the main strategies include: implementing an energy auditing and guidance system for large energy users, and promoting voluntary energy-conservation programs by the targeted energy users.

Figure 2. Variations of energy intensity in Taiwan in the past decade.

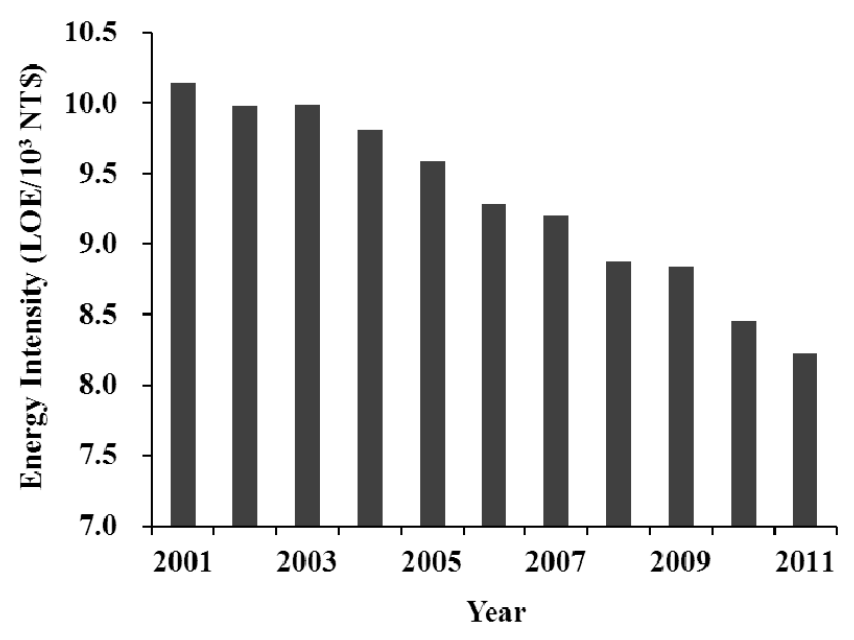

To promote CHP system for the purpose of upgrading efficient utilization of energy in the process industries, the central competent authority implemented a compliance regulation ("Measures for Implementing the Cogeneration System") on July 15, 1988. Thereafter, total installed capacity of CHP systems was on an increasing trend as seen in Figure 2 [6]. By the early of 2012, all CHP systems in the Taiwan area were listed in Table 1 [6]. Some important features in Table 1 and Figure 3 are pointed out as follows:

- Total number of cogeneration systems was 93, of which 29 were from public services (including 24 municipal solid waste incineration plants and five sanitary landfills), 11 were from petrochemical plants, 10 were from paper and pulp plants, nine were from synthetic fiber plants, eight were from food plants (including four sugar refineries, which utilize their agrowaste bagasses as auxiliary fuel for generating steam and electricity), six were from plastics plants, and 20 were other plants;

- Total installed capacity of CHP systems amounted to 7,612 MW, of which 3,303 MW (43.4\%) from petrochemical plants, $880 \mathrm{MW}(11.6 \%)$ from plastics plants, $792 \mathrm{MW}(10.4 \%)$ were from synthetic fiber plants, $633 \mathrm{MW}(8.3 \%)$ were from public services, $629 \mathrm{MW}(8.3 \%)$ were from iron and steel plant, $529 \mathrm{MW}(6.9 \%)$ were oil and oil refining plants, and $847 \mathrm{MW}(11.1 \%)$ were from other plants;

- In the past two decades (1990-2010), annually average growth of total installed capacity from CHP systems was about $11.34 \%$ according to the data in Figure 3. Obviously, the annual growth rate was larger than that (i.e., 5.17\%) of total electricity supply at the same period as described above. 
Figure 3. Installed capacity of CHP system in Taiwan during the 1990-2010 period.

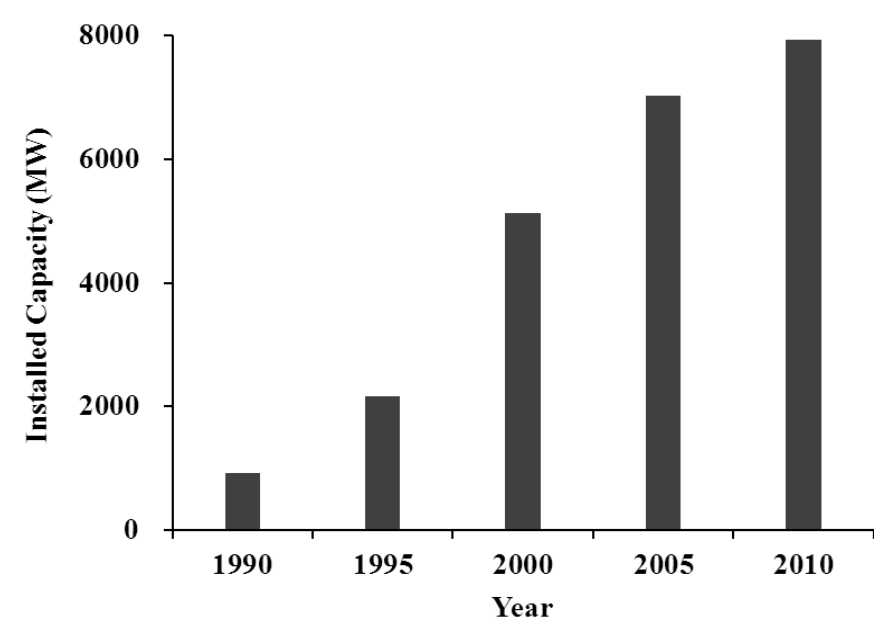

Table 1. Updated statistics of installed capacity of qualified CHP systems in Taiwan ${ }^{\text {a }}$.

\begin{tabular}{cccc}
\hline Industrial classification & No. of CHP plant & Installed capacity (kW) & Percentage (\%) \\
\hline Food & $8^{\mathrm{b}}$ & 60,850 & 0.80 \\
Synthetic fiber & 9 & 792,124 & 10.40 \\
Textile & 3 & 34,720 & 0.46 \\
Paper and pulp & 10 & 274,361 & 3.60 \\
Petrochemical & 11 & $3,303,263$ & 43.39 \\
Plastics & 6 & 880,023 & 11.56 \\
Basic chemical & 4 & 92,400 & 1.21 \\
Oil and oil refining & 4 & 528,600 & 6.94 \\
Cement & 1 & 25,100 & 0.33 \\
Iron and steel & 2 & 628,700 & 8.26 \\
Gas fuel supply & 1 & 500 & 0.01 \\
Cogeneration (CHP) & 6 & 264,664 & 3.48 \\
Public service & $29^{\mathrm{c}}$ & 632,946 & 8.31 \\
Electronic & 2 & 94,700 & 1.24 \\
Total & 93 & $7,612,951$ & 100 \\
\hline
\end{tabular}

Notes: ${ }^{a}$ Source [6]: the statistical data was updated on 23 February 2012. ${ }^{b}$ Including 4 sugar mills and 5 food processing plants; ${ }^{\mathrm{c}}$ Including $24 \mathrm{MSW}$-to-power plants and 5 biogas-to-power plants.

Furthermore, a preliminary comparison of the installed capacity statistics of CHP of Japan and Korea was addressed to reflect seriously on the energy saving management in the neighboring countries. By the end of 2009, total installed capacity of CHP systems in Japan amounted to about 9,200 MW, of which 7,300 MW (79\%) was from the industrial sector, and 1,900 MW (22\%) from the commercial and residential sectors. The former mainly includes chemical, machinery and steel industries. The latter was mostly used by hospitals, hotels, buildings and gymnasiums. In recent years, the CHP in Japan has been promoted to adopt low-carbon technologies like gas-fired and fuel cell systems. By contrast, total installed capacity of CHP systems in Korea totaled around 6,000 MW in 2007. This country is making CHP more efficient by using district heating and cooling (DHC) in the industrial sector, and more climate-friendly by fuel cell system in the commercial and residential sectors. 


\section{Regulatory Compliance with CHP Systems}

According to the national energy statistics by the central competent authority [1], the total energy consumption in 2010 amounted to about 120.31 million KLOE, of which $60.78 \%$ was used in the energy and industrial sectors. As mentioned above, CHP systems are the simultaneous production of electricity and heat in one single process for dual output streams so as to maximize its thermal efficiency of up to $80 \%$. However, about $45 \%$ of the energy potential contained in the fed fuel can be converted into electricity in the conventional power system. In order to improve the performance efficiency in the industrial and energy sectors of Taiwan, there are two important regulations in compliance with CHP systems: Energy Management Law and Environmental Impact Assessment Act.

\subsection{Energy Management Law}

In response to the energy crisis in the 1970s, the Taiwanese government first promulgated the Energy Management Law (EML) in August 1980, which was recently revised on 8 July 2009. The principal purpose of the Law is to aim at rational and efficient utilization of energy, including fuels and waste. According to the newly revised EML, important features concerning the aspects of CHP systems are stipulated in Article 10, which was summarized as follows:

- The energy user, which generates the amount of steam set up by the central competent authority, should install the cogeneration system. As a result, the referred energy users include industrial (electronics, chemicals, steel, textile, paper and pulp, cement, food, and refinery), energy (fired power and cogeneration), waste management (i.e., waste incineration) and other non-manufacturing plants;

- The energy user, which meets the levels of effective thermal ratios and total thermal efficiencies set up by the central competent authority in its CHP system, may ask the local vertical integrated utilities (e.g., Taipower) to purchase its excess electricity and supply backup electricity needed for its system maintenance or at the time of system breakdown;

- The central authority shall stipulate an implementation regulation regarding the rates for the purchase of excess electricity, the levels and verification of effective thermal ratios and total thermal efficiencies, the tie-in between the systems of the energy user and the vertical integrated utilities, the method of purchasing electrical energy, the rates for electricity and backup electricity purchased, and the duration of the obligation to purchase excess electricity by the vertical integrated utilities. In this regard, the current feed-in tariff price for purchasing surplus cogeneration electricity is connected with the electricity selling price of Taipower, which takes into account the power generation cost or power supply capacity for semi-peak hour in the promulgated the regulation (i.e., "Measures for Implementing the Cogeneration system", described later). The regulatory measure will indirectly make the feed-in tariff price of excess cogeneration electricity more reasonable.

Under the authorization of the Law, the Ministry of Economic Affairs (MOEA) has promulgated the relevant regulation (i.e., "Measures for Implementing the Cogeneration system") since September 2002. According to the Provision 5 of the regulation, a qualified CHP system is defined as referring to the registered energy user and its levels of effective thermal ratio [= effective heat output $\div$ (effective 
heat output + effective electricity output $)] \geq 20 \%$ and total thermal efficiency $[=$ (effective heat output + effective electricity output $) \div$ heating value of fuel) $] \geq 52 \%$, or the registered system specified in treating wastes. Also, the registered energy user should establish its own energy audit system (e.g., installing electricity meter to record daily electricity usage, reporting the monthly statistics to the central competent authority, performing the energy management by an qualified and registered personnel) in conjunction with objectives for energy conservation and the implementing plan which shall be carried out upon approval by the central competent authority. In 2009, the central competent authority selected 14 qualified power plants with CHP systems to carry out inspection and guidance for their total thermal ratios and effective thermal efficiencies [7]. With regard to efficiency inspection, eight CHP plants that completed the inspection were qualified under Article 5 of the Regulation, with the total thermal efficiency of 54\% and effective thermal ratio of $50 \%$.

\subsection{Environmental Impact Assessment Act}

The preventative approaches towards environmental protection and pollution prevention started in the end of 1980s in Taiwan. As a consequence, the introduction of environmental impact assessment (EIA) could significantly strengthen the prevention and mitigation of adverse impacts at the early stage of development activities. Article 5 of Environmental Impact Assessment Act (EIAA), first promulgated in December 1994 and recently revised in January 2003, authorizes the central competent authority to conduct EIA for the development activities that are likely to cause adverse impacts on the environment. Further, the resulting regulations (i.e., "Working Guidelines for Environmental Impact Assessment of Development Activities" and "Standards for Determining Specific Items and Scope of Environmental Impact Assessment for Developing Activities") promulgated by the central authority under the authorization of EIAA requires those prescribed development activities that EIA shall be conducted, and shall install CHP system to increase the energy use efficiency and provide the thermal energy in the industrial parks if it is feasible. For example, the EIA shall be conducted for the CHP systems of thermal power plants, which are located in land for non-city use and the use of gas fuel over $200,000 \mathrm{~kW}$ (power capacity), or oil, coal and other fuels over 100,000 kW (power capacity). However, the installed capacity of a multiple cycle generating unit with no added auxiliary fuel can be increased 1.5 times.

Comparing the data in Table 2, the installed CHP system capacity in 2000 was significantly larger than with that in 1995, implying that the regulatory policies discussed should have an important impact on the decision to install CHP system in the industrial sector. More importantly, this progress, thereby having a significant effect on decentralization of electricity power sources and optimization of power supply reliability, should be also due to the economic incentive measures including subsidiary grant/grant, feed-in tariff, tax relief and low-interest loan, etc.

\section{Preliminary Benefit Analysis from CHP Systems}

Concerning the benefits of mitigating greenhouse gases (GHG) emissions to the environment, a simple method (Tier 1 method) adopted by the Intergovernmental Panel on Climate Change (IPCC) was used to estimate equivalent $\mathrm{CO}_{2}$ emissions mitigation from the $\mathrm{CHP}$ systems for electricity generation (assumed in the present work) [8]. The IPCC methodology is based on the net quantities of 
electricity generated and average default emission factor (DEF). Therefore, the equivalent mitigations of $\mathrm{CO}_{2}$ emissions from the CHP systems for electricity generation in comparison with $\mathrm{GHG}$ emissions from the fossil fuel-fired power plant can be calculated by multiplying levels of CHP activity (power generation in $\mathrm{kWh}$ ) with DEF ( $\mathrm{kg} \mathrm{CO} / \mathrm{kWh}$ ). Based on the statistical weighting calculation by the state-owned company in Taiwan (Taipower Co.), the default value in terms of the equivalent amount of $\mathrm{CO}_{2}$ produced per $\mathrm{kWh}$ is about $0.54 \mathrm{~kg} \mathrm{CO} / \mathrm{kWh}$. Using the reported data on total net power generation of about 35,626 GWh in 2011 from the CHP systems [1], the equivalent mitigation of $\mathrm{CO}_{2}$ (Gg) from the CHP systems for electricity generation was thus calculated as given below: Equivalent mitigation of $\mathrm{CO}_{2}(\mathrm{Gg})=0.56 \mathrm{~kg} / \mathrm{kWh} \times 35,626 \mathrm{GWh} \times 10^{6} \mathrm{kWh} / \mathrm{GWh} \times 10^{-6} \mathrm{Gg} / \mathrm{kg} \approx 20,000 \mathrm{Gg}$.

\section{Conclusions}

In Taiwan, the basic principle of a sustainable energy policy is to establish a high efficiency, high value-added, low emission, and low dependency energy consumption and supply system. In this regard, CHP systems have been promoted through a regulatory framework under the Energy Management Law in the past two decades. In 2011, total installed CHP system capacity amounted to about 8,000 MW. Also, total net power generation is about 35,626 GWh from the CHP systems during the same period. As a result, the quantitative benefit from electricity supply by all installed CHP systems was preliminarily calculated to be around $20,000 \mathrm{Gg} /$ year. To encourage the investment in CHP systems as an energy-efficiency improvement and a measure for the reduction of greenhouse gases emissions, and also achieve the government goal (i.e., total installed capacity reached 1,000 MW) in 2020, the Renewable Energy Development Act, which has been passed in June 2009, will further promote the combustible biomass residues to co-combust with fossil fuels in the process industries and thermal power plants with CHP systems. This is due to the fact that the surplus electricity shall be sold to the state-owned company (Taipower) at an officially designated rate.

\section{Acknowledgments}

This research was partly supported by NSC (National Science Council), Taiwan, under contract NSC 100-3113-S-020-002 (Technical talent cultivation for bio-energy industry in southern Taiwan).

\section{Conflict of Interest}

The author declares no conflict of interest.

\section{References}

1. Energy Statistics Handbook -2010 [in Chinese]; Bureau of Energy (BOE): Taipei, Taiwan, 2011.

2. Statistics on Emissions of $\mathrm{CO}_{2}$ from Combustion and Its Analysis [in Chinese]; Bureau of Energy (BOE): Taipei, Taiwan, 2011.

3. Huang, Y.H.; Wu, J.H. Energy policy in Taiwan: Historical developments, current status and potential improvements. Energies 2009, 2, 623-645.

4. Turner, W.D. Cogeneration. In Handbook of Energy Efficiency and Renewable Energy; Kreith, F., Goswami, D.Y., Eds.; CRC Press: Boca Raton, FL, USA, 2007; pp. 17:1-17:41. 
5. Tsai, W.T.; Hsien, K.J. An analysis of cogeneration system utilized as sustainable energy in the industrial sector in Taiwan. Renew. Sustain. Energy Rev. 2007, 11, 2104-2120.

6. Statistical Database on Cogeneration System; Bureau of Energy (BOE): Taipei, Taiwan. Available online: http://web3.moeaboe.gov.tw/ECW/populace/content/wHandMenuFile.ashx?menu_id=996 (accessed on 28 September 2012).

7. Counseling to Promote Cogeneration System Setup and Economic Analysis Study in 2010; Taiwan Research Institute (TRI): Taipei, Taiwan Available online: http://www.tri.org.tw/english/ research_e/research3.php?id=11 ( accessed on 16 December 2012).

8. Tsai, W.T. Analysis of the sustainability of reusing industrial wastes as energy source in the industrial sector of Taiwan. J. Clean. Prod. 2010, 18, 1440-1445.

(C) 2013 by the authors; licensee MDPI, Basel, Switzerland. This article is an open access article distributed under the terms and conditions of the Creative Commons Attribution license (http://creativecommons.org/licenses/by/3.0/). 